\title{
Penentuan pH optimum untuk pertumbuhan kepiting bakau Scylla serrata dalam wadah terkontrol
}

\section{Optimum pH determination for mangrove crab Scylla serrata growth in controlled containers}

\author{
Yuni Puji Hastuti ${ }^{1 *}$, Horas Nadeak ${ }^{1}$, Ridwan Affandi², Kurnia Faturrohman ${ }^{1}$ \\ ${ }^{1}$ Departemen Budidaya Perairan, Fakultas Perikanan dan Ilmu Kelautan, Institut Pertanian Bogor \\ ${ }^{2}$ Departemen Manajemen Sumberdaya Perairan, Fakultas Perikanan dan Ilmu Kelautan, Institut Pertanian Bogor \\ Kampus IPB Dramaga Bogor, Jawa Barat 16680 \\ *Surel: yuni_ph2@yahoo.com
}

\begin{abstract}
One of the abiotic factors that affects the growth and the survival of crabs is $\mathrm{pH}$. The optimum $\mathrm{pH}$ media will give maximum impact on mangrove crabs because it is related with the osmoregulation process. This study aimed to examine the effect of $\mathrm{pH}$ on the survival rate (SR) and specific growth rate (SGR) of mangrove crab Scylla serrata through the reaction of physiological condition. This study consisted of the treatments with the $\mathrm{pH}$ medium 5 (A), $\mathrm{pH}$ medium 6 (B), $\mathrm{pH}$ medium 7 (C), and $\mathrm{pH}$ medium 8 (D). The crab's maintenance in different $\mathrm{pH}$ gave a significant effect $(\mathrm{P}<0.05)$ on the survival rate of the crabs. The $\mathrm{pH}$ treatments also gave a significant effect $(\mathrm{P}<0.05)$ on the SGR of the crabs. The low level of crab stress at $\mathrm{pH} 7$ was described by the total value of high hemocyte and the high osmotic load so that the $\mathrm{pH} 7$ was the optimum condition for the crabs.
\end{abstract}

Keywords: $\mathrm{pH}$, survival, specific growth rate, mangrove crabs

\begin{abstract}
ABSTRAK
Salah satu faktor abiotik yang mempengaruhi pertumbuhan dan kelangsungan hidup kepiting adalah $\mathrm{pH}$. Media $\mathrm{pH}$ optimum akan memberikan dampak maksimum pada kepiting bakau karena terkait dengan proses osmoregulasi. Penelitian ini bertujuan untuk menguji pengaruh $\mathrm{pH}$ pada tingkat kelangsungan hidup (SR) dan laju pertumbuhan spesifik (SGR) kepiting mangrove Scylla serrata melalui reaksi kondisi fisiologis. Penelitian ini terdiri atas perlakuan dengan media $\mathrm{pH} 5$ (A), sedang pH 6 (B), sedang $\mathrm{pH} 7$ (C), dan menengah pH 8 (D). Pemeliharaan kepiting di $\mathrm{pH}$ yang berbeda memberikan pengaruh yang signifikan $(\mathrm{P}<0,05)$ pada tingkat kelangsungan hidup kepiting. Perlakuan $\mathrm{pH}$ juga memberikan efek yang signifikan $(\mathrm{P}<0,05)$ pada SGR dari kepiting. Rendahnya tingkat stres kepiting pada $\mathrm{pH} 7$ digambarkan oleh nilai total hemosit tinggi dan beban osmotik tinggi sehingga $\mathrm{pH}$ 7 adalah kondisi optimum untuk kepiting.
\end{abstract}

Kata kunci: $\mathrm{pH}$, kelangsungan hidup, laju pertumbuhan spesifik, kepiting mangrove

\section{PENDAHULUAN}

Kepiting bakau Scylla serrata merupakan salah satu jenis komoditas laut yang potensial untuk dibudidayakan karena mempunyai nilai ekonomis tinggi. Produksi kepiting termasuk kepiting bakau $S$. serrata dan kepiting soka di Indonesia mengalami peningkatan setiap tahunnya. Jumlah produksi Crustacea dunia telah mengalami peningkatan sebesar $9,7 \%$ dari tahun 1990-2010. Berdasarkan data yang tersedia di Departemen Kelautan dan Perikanan, pada tahun 2000 ekspor kepiting mencapai 12.381 ton dan meningkat menjadi 22.726 ton pada tahun 2007. Berdasarkan jumlah produksi Crustacea tersebut, terdapat produksi jenis kepiting sebesar 200.000 ton pada tahun 2010 (FAO, 2011). Kementerian Kelautan dan Perikanan (KKP) juga telah mencanangkan program tahun 2009-2014 untuk meningkatkan produksi perikanan budidaya dan menetapkan sembilan komoditas unggulan termasuk jenis kepiting. Kepiting termasuk ke dalam komoditas lainnya dengan target peningkatan sebesar $188 \%$ sampai tahun 2014 (KKP, 2010). Tahun 2000, ekspor kepiting mencapai 12.381 ton dan meningkat 
menjadi 22.726 ton pada tahun 2007, hal ini berarti telah terjadi peningkatan ekspor kepiting sebesar $183,5 \%$ pada tahun 2000-2007. Namun demikian, kenaikan ekspor ini tidak diimbangi dengan peningkatan populasi kepiting tersebut (Siahainenia, 2009).

Budidaya kepiting bakau telah banyak dilakukan melalui berbagai sistem budidaya seperti manipulasi lingkungan dan pemotongan anggota tubuh, tetapi produksi kepiting soka di Indonesia masih relatif rendah baik kuantitas dan kualitasnya. Di Indonesia dikenal ada dua macam kepiting sebagai komoditas perikanan yang diperdagangkan, yang pertama adalah kepiting laut atau rajungan dan yang kedua adalah kepiting bakau yang dikenal sebagai " $m u d$ crab" dalam perdagangan internasional dan bahasa latinnya S. serrata. Kepiting bakau merupakan salah satu spesies yang potensial untuk dibudidayakan, karena memiliki nilai ekonomis penting di wilayah Indo-Pasifik, terutama kepiting yang matang gonad atau sudah bertelur, dewasa, dan gemuk (Sangari \& Toloh, 2015).

Secara garis besar, sistem budidaya kepiting bakau yang telah dikenal oleh masyarakat adalah pembesaran benih menjadi kepiting ukuran konsumsi, penggemukan, produksi kepiting cangkang lunak, dan produksi kepiting bertelur. Kepiting bakau ditangkap dari perairan estuaria dan saluran petak tambak. Kepiting bakau lebih suka hidup di perairan yang relatif dangkal dengan dasar berlumpur. Daerah yang cocok untuk lokasi budidaya kepiting ialah tambak yang dasarnya berlumpur dengan suhu air $25-35{ }^{\circ} \mathrm{C}$, $\mathrm{pH}$ 7,0-9,0, dissolved oxygen (DO) lebih dari 5 ppm, dan kadar garam berkisar 10-30 ppt (FAO, 2011).

Upaya untuk meningkatkan vitalitas kepiting perlu dilakukan guna menghasilkan kepiting dengan pertumbuhan yang pesat dan tingkat kelangsungan hidup yang tinggi. Untuk menghasilkan pertumbuhan kepiting bakau yang maksimal diperlukan media pemeliharaan yang sesuai untuk kinerja pertumbuhan yang optimal. Media pH yang optimum akan memberikan dampak pertumbuhan yang maksimum pada kepiting bakau karena berkaitan dengan derajat keasaman dan kebasaan di dalam perairan. $\mathrm{pH}$ di dalam perairan akan berpengaruh besar terhadap kelangsungan hidup kepiting bakau $S$. serrata. Oleh sebab itu, penelitian ini bertujuan untuk mengetahui nilai $\mathrm{pH}$ optimum pada media pemeliharaan untuk menunjang kinerja pertumbuhan kepiting bakau S. serrata.

\section{BAHAN DAN METODE}

\section{Rancangan penelitian}

Percobaan ini menggunakan rancangan acak lengkap (RAL) yang terdiri atas empat perlakuan dan masing-masing menggunakan tiga ulangan. Perlakuan yang diberikan yaitu pemeliharaan kepiting pada media dengan $\mathrm{pH}$ berbeda. Berikut merupakan perlakuan $\mathrm{pH}$ media pemeliharaan kepiting:

Perlakuan A: pemeliharaan pada media $\mathrm{pH} 5$ Perlakuan B: pemeliharaan pada media pH 6 Perlakuan C: pemeliharaan pada media $\mathrm{pH} 7$ Perlakuan D: pemeliharaan pada media $\mathrm{pH} 8$

\section{Persiapan wadah}

Wadah pemeliharaan merupakan box fiber berukuran $40 \times 60 \times 40 \mathrm{~cm}^{3}$. Penelitian ini juga menggunakan sistem resirkulasi untuk setiap perlakuannya. Hal ini bertujuan untuk menjaga kualitas media pemeliharaan untuk tetap dalam kondisi yang diharapkan dan mengurangi penumpukan feses serta sisa pakan di wadah pemeliharaan (Rodriguez et al., 2007). Terdapat tiga wadah box fiber, satu tandon, dan satu pompa air yang disusun untuk setiap satu resirkulasi. Setiap wadah pemeliharaan dipasang satu aerasi untuk menjaga kestabilan oksigen. Tandon filter air berisi beberapa perlakuan yaitu filter fisik yang terdiri atas kapas filter, batu karang, dan pasir malang. Sementara untuk filter biologi menggunakan bioball. Air yang digunakan pada penelitian merupakan air payau yang berasal dari pengenceran air laut. Air laut yang memiliki salinitas $31 \mathrm{~g} / \mathrm{L}$ kemudian diencerkan dengan air tawar untuk menghasilkan salinitas $25 \mathrm{~g} / \mathrm{L}$ (Hastuti et al., 2013).

Air baku untuk media percobaan diambil sebanyak $1 \mathrm{~L}$ air dari masing-masing akuarium percobaan. Setiap air baku diberikan perlakuan berbeda sesuai dengan $\mathrm{pH}$ yang diinginkan. Pembutan $\mathrm{pH}$ 5, 6, dan 7 menggunakan larutan $10 \mathrm{~mL}$ HCL yang diencerkan dengan 100 $\mathrm{mL}$ akuades, sedangkan untuk membuat $\mathrm{pH}$ 8 menggunakan larutan 10 gram $\mathrm{NaOH}$ yang diencerkan dengan $100 \mathrm{~mL}$ akuades. Kualitas $\mathrm{pH}$ air pada wadah percobaan dan wadah air baku diukur menggunakan $\mathrm{pH}$ meter sebelum pembuatan $\mathrm{pH}$ perlakuan. Jika nilai $\mathrm{pH}$ pada setiap wadah diketahui, maka untuk membuat kisaran $\mathrm{pH}$ perlakuan pada air baku dengan memberikan $\mathrm{HCL}$ dan $\mathrm{NaOH}$ yang konsentrasinya dikonversikan terlebih dahulu. Jika air baku sudah memiliki $\mathrm{pH}$ yang sesuai maka air baku yang 
sudah disiapkan diteteskan ke dalam akuarium dengan debit tertentu secara gradual melalui selang infus sehingga pada akhir pemberian air baku diperoleh volume dan $\mathrm{pH}$ yang sesuai.

\section{Persiapan hewan uji dan pemeliharaan}

Hewan uji yang digunakan pada penelitian ini adalah $S$. serrata ukuran berat 25-105 g sebanyak 120 ekor untuk semua perlakuan dan ulangan berasal dari petani pengumpul di Karawang, Jawa Barat. S. serrata ditempatkan dalam wadah penampungan selama tiga hari terlebih dahulu untuk adaptasi dengan salinitas. S. serrata yang digunakan pada penelitian ini adalah sebanyak 30 ekor untuk setiap perlakuannya dan kepadatan benih yang digunakan adalah 10 ekor pada setiap ulangan. Benih yang ditebar memiliki panjang rata-rata $4,45 \pm 0,11 \mathrm{~cm}$, lebar rata-rata $6,27 \pm 0,16$ $\mathrm{cm}$, dan bobot rata-rata $51,27 \pm 3,58 \mathrm{~g}$ yang diukur menggunakan penggaris dan timbangan.

Pemeliharaan dilakukan selama 42 hari dengan pengelolaan kualitas air menggunakan sistem siphon atau pergantian kualitas air sebanyak $25 \%$ setiap tiga hari sekali. Air yang terbuang diganti dengan air yang volume dan $\mathrm{pH}$ yang sama. Selain ganti air, pengelolaan kualitas air juga dilakukan dengan cara mengukur suhu, $\mathrm{pH}$, DO, dan salinitas setiap hari untuk mengontrol kondisi kualitas air, sedangkan untuk pengukuran alkalinitas dan TAN dilakukan pada awal dan akhir pemeliharaan. Jenis pakan terbaik untuk menunjang pertumbuhan $S$. serrata yang optimal adalah ikan rucah (ikan selar, ikan pepetek, dan lain-lain). Pakan diberikan dengan frekuensi satu kali sehari, yaitu sore hari pukul 15.00-16.00 WIB. Jumlah pakan yang diberikan sekitar 2-4 $\%$ dari bobot biomassa (Aditya et al., 2012). Berikut beberapa parameter ukur yang diambil yang meliputi kinerja produksi, respons stres, dan kualitas air.

\section{Parameter yang diamati}

Parameter uji yang diamati pada penelitian ini dapat diamati pada Tabel 1. Waktu pengambilan sampel untuk uji kualitas air dan kinerja produksi dilakukan setiap satu minggu sekali. Pengukuran parameter respons stres seperti pengukuran tingkat kerja osmotik, total haemocyte count, dan glukosa hemolim dilakukan pada akhir masa pemeliharaan.

\section{Pengolahan dan analisis data}

Data yang didapatkan ditabulasi dan dianalisis menggunakan Microsoft Excel 2007 dan SPSS
16.0. Data yang diperoleh disajikan dalam bentuk tabel dan grafik. Data yang dianalisis meliputi analisis ragam untuk kinerja respons pertumbuhan dan respons stres, sedangkan analisis deskriptif digunakan untuk profil kualitas air. Analisis ragam (ANOVA) dengan uji F pada selang kepercayaan $95 \%$.

\section{HASIL DAN PEMBAHASAN}

\section{Hasil}

\section{Parameter kualitas air}

Pengukuran parameter kualitas air meliputi nilai $\mathrm{pH}$, oksigen terlarut, suhu, salinitas, alkalinitas, total ammonia nitrogen (TAN), dan total suspended solid (TSS) seperti yang disajikan pada Tabel 2.

Berdasarkan pengukuran parameter fisikakimia air pada media pemeliharaan kepiting bakau dengan sistem resirkulasi selama masa pemeliharaan, kisaran nilai kualitas air masih layak untuk mendukung kehidupan kepiting bakau karena berada pada kisaran yang telah ditentukan.

\section{Kinerja respons stres}

Parameter kinerja respons stres meliputi kadar glukosa hemolim, tingkat kerja osmotik, total haemocyte count dan tingkat konsumsi oksigen (TKO).

\section{Kadar glukosa hemolim}

Hasil uji kadar glukosa hemolim selama penelitian disajikan pada Gambar 1. Dari data tersebut menunjukkan bahwa setiap perlakuan memiliki nilai kadar glukosa hemolim yang berbeda nyata $(\mathrm{P}<0,05)$. Nilai glukosa terendah pada akhir pemeliharaan terjadi pada perlakuan pH 7 yaitu $21 \mu \mathrm{mol} / \mathrm{L}$. Nilai glukosa tertinggi terdapat pada perlakuan $\mathrm{pH} 8$ yaitu $34 \mu \mathrm{mol} / \mathrm{L}$ pada akhir masa pemeliharaan. Perlakuan $\mathrm{pH}$ 5 tidak memiliki data kadar glukosa pada akhir masa pemeliharaan dikarenakan data tingkat kelangsungan hidup $0 \%$.

\section{Tingkat kerja osmotik (TKOs)}

Hasil uji tingkat kerja osmotik selama penelitian disajikan pada Gambar 2. Dari data tersebut menunjukkan bahwa setiap perlakuan memiliki nilai TKOs yang tidak berbeda nyata $(\mathrm{P}<0,05)$. Perlakuan media $\mathrm{pH} 6, \mathrm{pH} 7$, dan $\mathrm{pH} 8$ memiliki nilai TKOs berturut-turut sebesar 0,668 $\mathrm{mOsm} / \mathrm{L} \mathrm{H} 2 \mathrm{O}, 0,666 \mathrm{mOsm} / \mathrm{L} \mathrm{H} 2 \mathrm{O}$ dan 0,656 $\mathrm{mOsm} / \mathrm{L} \mathrm{H} 2 \mathrm{O}$. Ketiga data diatas Perlakuan 
Tabel 1. Parameter uji selama penelitian

\begin{tabular}{|c|c|c|c|}
\hline & Parameter & Satuan & Alat ukur / metode \\
\hline \multirow[t]{7}{*}{ Kualitas air } & suhu & ${ }^{\circ} \mathrm{C}$ & termometer \\
\hline & oksigen terlarut (OT) & $\mathrm{mg} / \mathrm{L}$ & DOmeter \\
\hline & $\mathrm{pH}$ & - & pHmeter \\
\hline & total suspended solid (TSS) & $\mathrm{mg} / \mathrm{L}$ & timbangan \\
\hline & $\operatorname{amonia}\left(\mathrm{NH}_{3}\right)$ & $\mathrm{mg} / \mathrm{L}$ & spektrofotometri \\
\hline & alkalinitas total & $\mathrm{mg} / \mathrm{L}$ & titrimetrik \\
\hline & salinitas & $\mathrm{mg} / \mathrm{L}$ & titrimetrik \\
\hline \multirow[t]{4}{*}{ Kinerja respons stres } & tingkat konsumsi oksigen & $\mathrm{mg} \mathrm{O}_{2} / \mathrm{g} / \mathrm{jam}$ & Liao \& Huang (1975) \\
\hline & tingkat kerja osmotik & $\mathrm{mOsm} / \mathrm{L} \mathrm{H}_{2} \mathrm{O}$ & Lignot et al. (2000) \\
\hline & total haemocyte count & $\mathrm{sel} / \mathrm{mm}^{3}$ & Blaxhall \& Daishley (1973) \\
\hline & glukosa hemolim & $\mu \mathrm{mol} / \mathrm{L}$ & glucose liquicolor \\
\hline \multirow[t]{4}{*}{ Kinerja produksi } & tingkat kelangsungan hidup & $\%$ & Goddard (1996) \\
\hline & laju pertumbuhan spesifik & $\% /$ hari & Huisman (1987) \\
\hline & pertambahan bobot mutlak & G & Huisman (1987) \\
\hline & rasio konversi pakan & & Goddard (1996) \\
\hline
\end{tabular}

Tabel 2. Parameter kualitas air pada wadah pemeliharaan kepiting bakau Scylla serrata selama pemeliharaan.

\begin{tabular}{lccccc}
\hline \multirow{2}{*}{ Parameter } & \multicolumn{2}{c}{ Perlakuan } & \multicolumn{2}{c}{ Standar FAO } \\
\cline { 2 - 5 } & $\mathrm{pH} \mathrm{5}$ & $\mathrm{pH} \mathrm{6}$ & $\mathrm{pH} \mathrm{7}$ & $\mathrm{pH}$ & 2011 \\
\hline Suhu & 29 & 29 & 29 & 29 & $25-35$ \\
Salinitas (g/L) & 25 & 25 & 25 & 25 & $20-35$ \\
TSS (mg/L) & $0,08-0,09$ & $0,084-0,076$ & $0,02-0,09$ & $0,01-0,14$ & $\geq 30$ \\
OT (mg/L) & $5,1-5,4$ & $4,5-5,5$ & $4,7-5,4$ & $4,6-5,1$ & $>5$ \\
pH & 5 & 6 & 7 & 8 & $7-9$ \\
Alkalinitas (mg/L) & 0 & $95-100$ & $75-80$ & $80-85$ & $>80$ \\
TAN (mg/L) & $0,03-1,26$ & $0,078-1,255$ & $0,012-1,494$ & $0,058-1,452$ & $<3$ \\
\hline
\end{tabular}

A tidak memiliki data TKOs pada akhir masa pemeliharaan dikarenakan data tingkat kelangsungan hidup $0 \%$.

\section{Total haemocyte count}

Hasil uji total haemocyte count (THC) pada akhir masa pemeliharaan disajikan pada Gambar 3. Berdasarkan hasil yang diperoleh, perlakuan media pH 7 memiliki nilai THC tertinggi yaitu sebesar $1,7 \mathrm{sel} / \mathrm{mm} 3$. Nilai THC pada perlakuan media pH 6 dan pH 8 memiliki hasil yang tidak berbeda nyata $(\mathrm{P}<0,05)$ yaitu berturut-turut sebesar $1,4 \mathrm{sel} / \mathrm{mm} 3$ dan $1,5 \mathrm{sel} / \mathrm{mm}^{3}$. Perlakuan A tidak memiliki data THC pada akhir masa pemeliharaan karena tidak adanya hewan uji yang bertahan hidup (data tingkat kelangsungan hidup bernilai $0 \%$ ).

\section{Tingkat konsumsi oksigen (TKO)}

Hasil uji tingkat konsumsi oksigen selama penelitian disajikan pada gambar 4. Dari data tersebut setiap perlakuan memiliki hasil yang berbeda nyata $(\mathrm{P}<0,05)$. Perlakuan $\mathrm{pH} 6$ mempunyai nilai TKO tertinggi yaitu sebesar 0,021 $\mathrm{mgO} 2 / \mathrm{g} / \mathrm{jam}$. Nilai TKO untuk perlakuan pH 7 dan $\mathrm{pH} 8$ berturut-turut sebesar 0,006 mgO2/g/jam dan 0,009 mgO2/g/jam. Perlakuan A tidak memiliki data TKO pada akhir masa pemeliharaan karena data tingkat kelangsungan hidup $0 \%$. 


\section{Parameter kinerja produksi}

Parameter kinerja produksi yang diamati dalam penelitian ini meliputi tingkat kelangsungan hidup (TKH), laju pertumbuhan spesifik (LPS), pertumbuhan bobot mutlak (PBM), dan rasio konversi pakan (RKP) seperti yang disajikan pada Tabel 3.

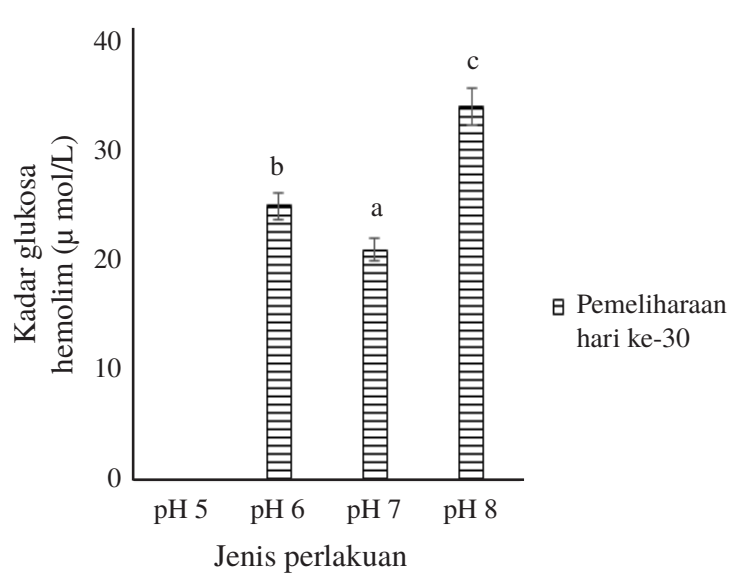

Gambar 1. Kadar glukosa hemolim kepiting bakau Schylla serrata pada setiap perlakuan pada akhir masa pemeliharaan. Huruf berbeda di atas diagram menunjukkan hasil yang berbeda nyata $(\mathrm{P}<0,05)$.

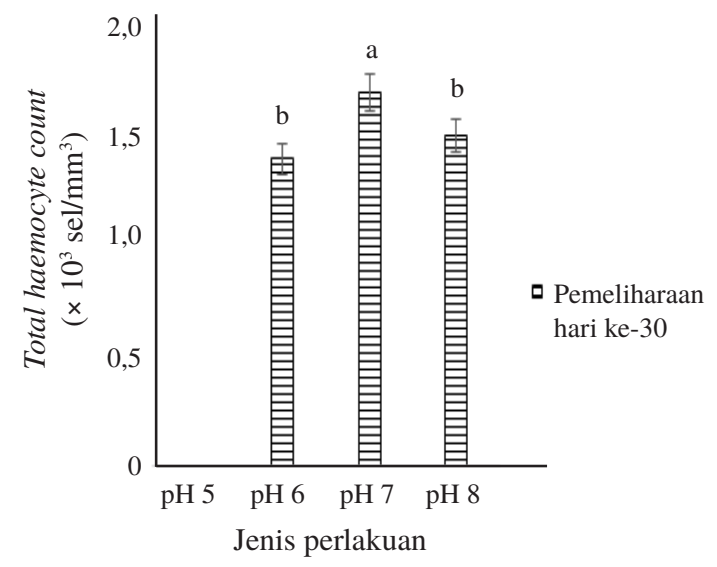

Gambar 3. Total haemocyte count kepiting bakau Schylla serrata pada setiap perlakuan pada akhir masa pemeliharaan. Huruf berbeda di atas diagram menunjukkan hasil yang berbeda nyata $(\mathrm{P}<0,05)$.
Hasil uji analisis ragam (ANOVA) menunjukkan bahwa perlakuan memberikan pengaruhnyataterhadapnilaitingkatkelangsungan hidup (TKH), nilai laju pertumbuhan spesifik (LPS), pertumbuhan bobot mutlak (PBM) dan rasio konversi pakan (RKP) $(\mathrm{P}<0,05)$. Nilai $\mathrm{TKH}$ tertinggi terdapat pada perlakuan $\mathrm{C}$

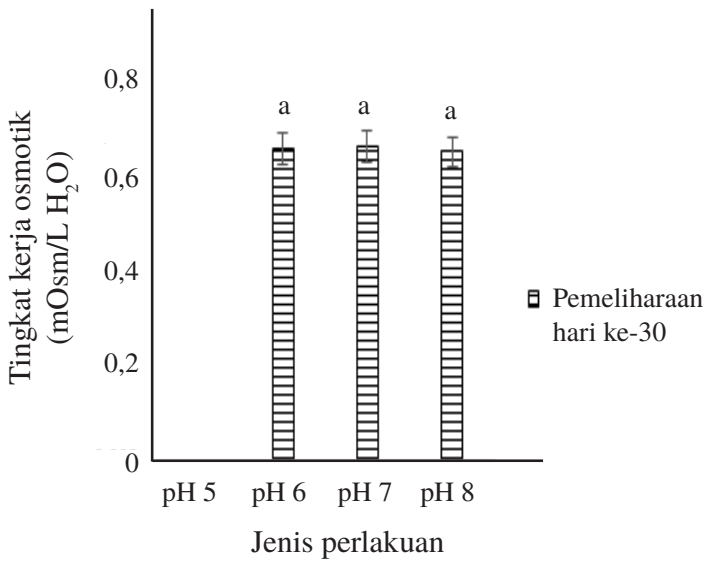

Gambar 2. Tingkat kerja osmotik kepiting bakau Schylla serrata pada setiap perlakuan pada akhir masa pemeliharaan. Huruf yang sama di atas diagram menunjukkan hasil yang tidak berbeda nyata $(P>0,05)$.

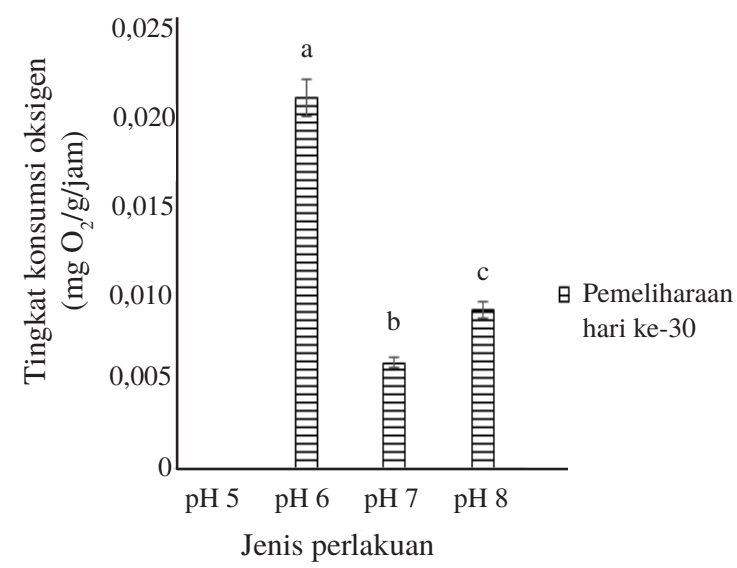

Gambar 4. Tingkat konsumsi oksigen kepiting bakau Schylla serrata pada setiap perlakuan pada awal dan akhir masa pemeliharaan. Huruf berbeda di atas diagram menunjukkan hasil yang berbeda nyata $(\mathrm{P}<0,05)$.

Tabel 3. Kinerja produksi kepiting bakau Scylla serrata pada perlakuan nilai $\mathrm{pH}$ yang berbeda ; A (pH 5), B (pH 6), C (pH 7), dan D (pH 8)

\begin{tabular}{lcccc}
\hline \multirow{2}{*}{ Parameter kinerja produksi } & \multicolumn{4}{c}{ Perlakuan penambahan titik aerasi } \\
\cline { 2 - 5 } & \multicolumn{1}{c}{$\mathrm{A}(\mathrm{pH} 5)$} & $\mathrm{B}(\mathrm{pH} 6)$ & $\mathrm{C}(\mathrm{pH} 7)$ & $\mathrm{D}(\mathrm{pH} 8)$ \\
\hline Tingkat kelangsungan hidup (\%) & $53,30 \pm 5,77 \mathrm{a}$ & $53,30 \pm 11,54 \mathrm{a}$ & $83,30 \pm 11,54 \mathrm{~b}$ & $0 \pm 0,00 \mathrm{c}$ \\
Laju pertumbuhan spesifik (\%/hari) & $7,40 \pm 0,07 \mathrm{a}$ & $8,10 \pm 0,04 \mathrm{a}$ & $10,20 \pm 0,06 \mathrm{~b}$ & $3,40 \pm 0,01 \mathrm{c}$ \\
Pertumbuhan bobot mutlak (g) & $2,80 \pm 0,30 \mathrm{a}$ & $2,90 \pm 0,20 \mathrm{a}$ & $4,20 \pm 0,40 \mathrm{~b}$ & $0,90 \pm 0,10 \mathrm{c}$ \\
Rasio konversi pakan (RKP) & $21,50 \pm 0,40 \mathrm{a}$ & $12,30 \pm 0,30 \mathrm{~b}$ & $7,20 \pm 0,10 \mathrm{c}$ & $9,10 \pm 0,60 \mathrm{~d}$ \\
\hline
\end{tabular}

Keterangan: angka-angka pada baris yang sama yang diikuti oleh huruf superskrip yang sama tidak berbeda nyata pada taraf uji 5\% (uji selang berganda Duncan). 
yaitu $86,7 \pm 3,27 \%$ dan terendah terdapat pada perlakuan D yaitu $0 \pm 0,00 \%$. Nilai LPS tertinggi terdapat pada perlakuan $\mathrm{C}$ yaitu $10,2 \pm 0,06 \%$ / ekor/hari dan terendah pada perlakuan $\mathrm{D}$ yaitu $3,4 \pm 0,01 \% /$ hari. Nilai PBM tertinggi terdapat pada perlakuan $\mathrm{C}$ yaitu $4,2 \pm 0,4 \mathrm{~g}$ dan terendah terdapat pada perlakuan D yaitu $0,9 \pm 0,1 \mathrm{~g}$. Nilai RKP terendah terdapat pada perlakuan $C$ yaitu $7,2 \pm 0,1$ dan tertinggi pada perlakuan A yaitu $21,5 \pm 0,4$.

\section{Pembahasan}

Penggunaan sistem resirkulasi selama pemeliharaan berlangsung, bertujuan untuk menjaga kestabilan kualitas air dan mengurangi pergantian air media karena air akan terus menerus mengalir melewati filter fisik dan filter biologi sehingga kekeruhan dapat diminimalisir. Menurut Jewlaika et al. (2014), padatan tersuspensi dan kekeruhan memiliki korelasi positif, akan tetapi tingginya padatan terlarut tidak selalu diikuti dengan tingginya kekeruhan. Air laut memiliki nilai padatan terlarut yang tinggi tetapi tidak berarti kekeruhannya juga tinggi. Nurhidayat et al. (2012) juga menjelaskan bahwa metode fisik pada dasarnya menerapkan prinsip filtrasi.

Filtrasi adalah proses pembersihan air dengan melewatkannya melalui suatu media berpori. Supriyono et al. (2007) menjelaskan bahwa filter fisik yang digunakan pada sistem resirkulasi yaitu berupa kapas filter, pasir malang, batu zeolit, dan batu karang yang disusun bertumpuk pada tandon filter. Filter biologi yang digunakan adalah bioball. Sifat pasir malang yang berongga halus dapat menjebak partikel-partikel seperti sisa feses dan pelet, sehingga pasir malang dapat menyaring kotoran-kotoran dari sisa feses dan pelet sesuai besar pori pasir tersebut. Zeolit merupakan mineral alumunia silikat terhidrat yang memiliki rongga berisi molekul air dan kation-kation bebas yang dapat dipertukarkan. Struktur yang berongga pada zeolit tersebut juga mampu menyerap atau menyaring sejumlah besar molekul yang berukuran lebih kecil atau sesuai dengan rongganya.

Filter biologi yang dipakai adalah bioball yang berperan sebagai media tempat pelekatan mikrob (bakteri nitrifikasi) yang berperan dalam mendegradasi amonia nitrogen kedalam bentuk nitrat yang tidak beracun bagi ikan (Dewi \& Masithoh, 2013). Menurut Badjoeri et al. (2010) bahwa kelimpahan dan aktivitas bakteri di sedimen berpengaruh terhadap konsentrasi senyawa toksik yang dapat mempengaruhi derajat kelangsungan hidup dan pertumbuhan biota yang dipelihara.

Berdasarkan pengukuran kualitas air media pemeliharaan kepiting pada sistem resirkulasi selama penelitian, kisaran nilai kualitas air masih layak untuk mendukung kehidupan kepiting. FAO (2011) menetapkan standar kualitas air untuk memelihara kepiting bakau, dengan kisaran DO optimum $>5$ ppm, suhu $25-35{ }^{\circ} \mathrm{C}, \mathrm{pH}$ 7,0-9,0, TAN $<3$ ppm, alkalinitas $>80 \mathrm{ppm}$, dan kekeruhan $>30 \mathrm{mg} / \mathrm{L}$. Data tersebut juga sesuai dengan (PerMen LH, 2009) bahwa kondisi kualitas air diatas sesuai dengan minimum kualitas air yang harus dicapai pada perairan umum.

Keberhasilan kegiatan budidaya kepiting, terutama kegiatan pembesaran dapat diamati dari produksi kepiting yang ditunjukkan oleh pertumbuhan yang pesat dalam waktu singkat dan tingkat kelangsungan hidup yang tinggi. Tingkat kelangsungan hidup antara lain dipengaruhi oleh $\mathrm{pH}$ lingkungan. $\mathrm{pH}$ dapat mempengaruhi struktur insang serta aktivitas enzim pada organ insang sehingga dapat mempengaruhi tingkat konsumsi oksigen (Salim et al., 2006). Apabila tingkat konsumsi menurun maka produksi energi akan menurun sehingga kebutuhan energi untuk aktivitas proses biosintes akan menurun juga (Tseng \& Hwang, 2008). Sistem osmoregulasi dan ekskresi akan terganggu, terganggu osmoregulasi akan menyebabkan tekanan osmotik cairan tubuh tidak ideal, dan hal ini akan menyebabkan laju biosintes akan terhambat dan akhirnya akan mengganggu pertumbuhan (Rusdi \& Karim, 2006).

Pengukuran tingkat konsumsi oksigen merupakan cara untuk mengukur laju metabolisme pada ikan (Herlinah, 2010). Oksigen terlarut dalam hal ini sangat berperan penting untuk menghasilkan energi melalui proses respirasi aerob. Hal ini sesuai Campbell et al. (2006) yang menyatakan dalam respirasi aerob, oksigen berperan sebagai penerima elektron terakhir untuk menghasilkan $\mathrm{H}_{2} \mathrm{O}$ (air) dan 38 ATP (energi). Dari data tersebut pada perlakuan $\mathrm{pH} 7$ mempunyai nilai TKO sebesar $0,006 \mathrm{mgO}_{2} / \mathrm{g} / \mathrm{jam}$ pada akhir pemeliharaan, sedangkan untuk nilai TKO tertinggi terdapat pada perlakuan $\mathrm{pH} 6$ yaitu $0,021 \mathrm{mgO}_{2} / \mathrm{g} / \mathrm{jam}$ pada akhir masa pemeliharaan. Perlakuan pH 5 tidak memiliki data TKO pada akhir masa pemeliharaan dikarenakan data SR $0 \%$. Meningkatnya konsumsi oksigen ketika $\mathrm{pH}$ media dibawah dan diatas pH 7 menunjukan bahwa adanya kegiatan laju metabolisme untuk melawan perubahannya $\mathrm{pH}$ media agar kondisi 
tubuh tetap stabil (daya homeostasi) dan adanya dugaan bahwa tingginya konsumsi oksigen tersebut untuk pembelanjaan energi osmoregulasi karena ketika $\mathrm{pH}$ media di luar optimal maka akan terjadi penurunan aktivitas enzim termasuk yang terkait dengan osmoregulasi (NaK ATPase) (Sousa et al., 2010). Karim (2007) menjelaskan bahwa secara fisiologis, pertumbuhan hanya dapat terjadi apabila terdapat kelebihan energi, setelah energi melalui pakan yang dikonsumsi dikurangi dengan kebutuhan energi untuk berbagai aktivitas. Terjadinya perubahan kondisi lingkungan terutama $\mathrm{pH}$ akan mempengaruhi jumlah energi yang digunakan terutama untuk keperluan osmoregulasi (Sartje, 2010).

Faktor lingkungan termasuk di dalamnya $\mathrm{pH}$ perairan yang secara langsung mempengaruhi organ pernapasan (insang). $\mathrm{pH}$ media akan mempengaruhi aktivitas enzim-enzim yang bekerja pada organ insang misalnya, ATPase, karbonie anhidrase, Na-K ATPase, dan aktivitas enzim pada insang tersebut berkaitan dengan laju respirasi, osmoregulasi, dan ekskresi (Nurdiani \& Zeng, 2007). Dengan demikian apabila $\mathrm{pH}$ lingkungan tidak optimal maka proses-proses diatas akan terhambat dan pada akhirnya akan mempengaruhi pertumbuhan. Salah satu parameter lingkungan yang mempengaruhi laju pertumbuhan adalah $\mathrm{pH}$ lingkungan (Nisa et al., 2013).

pH mempengaruhi laju pertumbuhan melalui kemampuan pada proses-proses fisiologis dan biokimiawi tersebut dan dapat juga mempengaruhi struktur insang serta aktivitas enzim pada organ insang sehingga dapat mempengaruhi tingkat konsumsi oksigen. Apabila tingkat konsumsi oksigen terganggu maka produksi energi akan menurun sehingga sistem osmoregulasi dan ekskresi akan terganggu. Terganggunya osmoregulasi akan menyebabkan tekanan osmotik cairan tubuh tidak ideal. Cairan osmotik tubuh yang tidak ideal menyebabkan laju biosintesis akan terhambat dan akhirnya akan mengganggu pertumbuhan (Gracia et al., 2006). Berdasarkan hasil penelitian Ma et al., (2010), perlakuan $\mathrm{pH}$ 5 ekstrim dapat mengurangi tingkat kekebalan kepiting, sehingga perlakuan kadar $\mathrm{pH}$ pada kepiting bakau $S$. serrata dapat mempengaruhi THC pada kepiting. Total hemosit yang diamati sangat penting untuk mengetahui peranannya dalam sistem imun kepiting dan tingkat resistensi kepiting terhadap serangan penyakit.

Hasil pengamatan menunjukkan bahwa perlakuan salinitas memberi pengaruh berbeda nyata $(\mathrm{P}<0,05)$ terhadap total hemosit kepiting (Gambar 3). Berdasarkan hasil pengamatan total hemosit pada penelitian ini menunjukkan bahwa perlakuan pH 7 memiliki nilai THC yang berbeda dibandingkan dengan perlakuan yang lain. Hal ini berarti bahwa pH 7 merupakan salinitas yang lebih baik daripada $\mathrm{pH}$ lainnya, karena pada perlakuan tersebut memiliki nilai THC yang lebih tinggi dibandingkan perlakuan yang lain. Vijayavel et al. (2007) menjelaskan bahwa terbentuknya selsel fagositik memiliki peluang lebih tinggi dalam pengendalian dari serangan patogen baik bakteri maupun virus dan mampu meningkatkan sistem imun.

Karim (2007) menjelaskan bahwa pada media dengan tingkat kerja osmotik di luar kisaran yang mendekati isoosmotik, maka kepiting akan melakukan kerja osmotik ekstra untuk mempertahankan osmotik tubuh yang ada di dalamnya. Hal tersebut menyebabkan pembelanjaan energi untuk osmoregulasi yang lebih tinggi sehingga mengurangi porsi energi untuk pertumbuhan. Perlakuan $\mathrm{pH}$ tidak memberi pengaruh yang berbeda nyata $(\mathrm{P}<0,05)$ terhadap tingkat kerja osmotik kepiting (Gambar 2). Kemampuan osmoregulasi pada setiap organisme akuatik dapat ditentukan dengan cara mengukur nilai osmolaritas hemolim dan membandingkan dengan nilai osmolaritas medianya. Perlakuan media pH 8 memiliki nilai tingkat kerja osmotik terendah dengan nilai sebesar 0,656 mOsm/L $\mathrm{H}_{2} \mathrm{O}$, sedangkan nilai TKOs tertinggi terdapat pada $\mathrm{pH} 7$ sebesar $0,666 \mathrm{mOsm} / \mathrm{L} \mathrm{H}_{2} \mathrm{O}$.

Glukosa hemolim berperan sebagai salah satu sumber energi metabolik untuk keperluan osmoregulasi. Salah satu faktor perubahan yang paling mempengaruhi adalah kondisi lingkungan. Kebutuhan energi untuk memperbaiki homeostasi selama stres dipenuhi oleh proses glikogenolisis dan glukoneogenesis yang menghasilkan glukosa (Ockwell, 2008). Pasokan glukosa ke dalam sel target sangat bergantung pada kinerja insulin. Kinerja insulin sangat dipengaruhi oleh kadar hormon kortisol. Kortisol bekerja untuk menghambat efek insulin dalam membantu penyerapan glukosa dalam darah oleh sel. Hal tersebut menyebabkan kadar glukosa dalam darah menjadi tinggi pada organisme yang mengalami stres (Watkins, 2008).

Perlakuan $\mathrm{pH}$ memberikan pengaruh yang berbeda nyata $(\mathrm{P}<0,05)$ terhadap kadar glukosa hemolim kepiting bakau (Gambar 1). Nilai glukosa terendah pada akhir pemeliharaan terjadi pada perlakuan $\mathrm{pH} 7$ yaitu $21 \mu \mathrm{mol} / \mathrm{L}$, 
sedangkan untuk nilai glukosa tertinggi terdapat pada perlakuan $\mathrm{pH} 8$ yaitu $34 \mu \mathrm{mol} / \mathrm{L}$ pada akhir masa pemeliharaan. Hal ini membuktikan adanya tingkat stress yang tinggi pada kepiting yang diberi perlakuan $\mathrm{pH} 8$.

Pemeliharaan kepiting pada $\mathrm{pH}$ yang berbeda memberi pengaruh nyata $(\mathrm{P}<0,05)$ terhadap tingkat kelangsungan hidup kepiting. Tingkat kelangsungan hidup pada perlakuan $\mathrm{pH} 7$ mencapai $86,67 \%$, sedangkan pada perlakuan $\mathrm{pH}$ 5 tingkat kelangsungan hidupnya $0 \%$. pH media melalui efek osmotiknya akan menentukan tingkat kerja osmotik yang dialami suatu organisme. Dampak osmotik tersebut selain menentukan tingkat kerja osmotik juga mempengaruhi tingkat kelangsungan hidup dan pertumbuhan (Karim, 2005). Kepiting melakukan kerja osmotik yang tinggi sebagai respons fisiologis untuk mempertahankan lingkungan internalnya pada kondisi hipoosmotik atau hiperosmotik. Hal ini menyebabkan terjadinya peningkatan konsumsi oksigen, penurunan aktivitas makan, dan aktivitas rutinitas.

Berdasarkan hasil penelitian, pertumbuhan bobot mutlak (PBM) dan laju pertumbuhan spesifik (LPS) tertinggi terdapat pada perlakuan pada $\mathrm{pH} 7$ yaitu sebesar $4,2 \pm 0,4 \mathrm{~g}$ dan $10,2 \pm 0,06 \%$ / hari. Hal ini didukung oleh nilai rasio konversi pakan yang rendah. Perlakuan $\mathrm{pH}$ memberi pengaruh yang nyata $(\mathrm{P}<0,05)$ terhadap rasio konversi pakan. Nilai RKP terendah terdapat pada perlakuan $\mathrm{pH} 7$ yaitu 7,2 $\pm 0,1$ dan tertinggi pada perlakuan pH 5 yaitu $21,5 \pm 0,4$. Tingkat konsumsi pakan yang tinggi mendorong ketersediaan energi bagi kepiting untuk pemenuhan kebutuhan dasar dan pemeliharaan membran sel tubuh (Arief et al., 2008). Hal ini berkaitan dengan nafsu makan yang tinggi yang diakibatkan oleh tingkat stres yang rendah, sehingga $\mathrm{pH} 7$ merupakan kondisi yang optimum bagi kepiting.

\section{KESIMPULAN}

Perlakuan $\mathrm{pH}$ terbaik bagi kinerja produksi yang meliputi parameter pertumbuhan dan sintasan kepiting adalah $\mathrm{pH}$ 7. Perlakuan $\mathrm{pH}$ 7 juga memiliki kinerja respons stres terbaik selama pemeliharaan ditunjang dengan parameter kualitas air yang optimum.

\section{DAFTAR PUSTAKA}

Aditya BP, Sunaryo, Djunaedi A. 2012. Pemberian pelet dengan ukuran berbeda terhadap pertumbuhan kepiting bakau Scylla serrata Forsskal, 1775. Journal of Marine Research 1: 171-177.

Arief M, Mufidah, Kusriningrum. 2008. Pengaruh penambahan probiotik pada pakan buatan terhadap pertumbuhan dan rasio konversi pakan ikan nila GIFT Oreochromis niloticus. Berkala Ilmiah Perikanan 3: 53-58.

Badjoeri M. Yuni Puji Hastuti, Tri Widiyanto, Iman Rusmana. 2010. Kelimpahan bakteri penghasil senyawa ammonium dan nitrit pada sedimen tambak sistem semiintensif. Limnotek 17: 102-111.

Blaxhall PC,Daysley KW. 1973. Routine haematological methods for use with fish blood. Journal Fish Biology 5: 577-581.

Campbell N A, Williamson B, Heyden RJ. 2006. Biology: Exploring Life. Boston (US): Pearson Prentice Hall.

Dewi YS, Masithoh M. 2013. Efektivitas teknik biofiltrasi dengan media bioball terhadap penurunan kadar nitrogen total. Jurnal Limit's 9: 45-53.

[FAO]. Food and Agriculture Organization. 2011. The state of word fisheries and aquaculture. Rome (IT): FAO.

Gracia LA, Rosas VC, Brito PR. 2006. Effects of salinity on physiological conditions in juvenile common snook Centropomus undecimalis. Comparative Biochemistry and Physiology 145: 340-345.

Hastuti YP, Affandi R, Safrina MD, Faturrohman K, Nurussalam W. 2013. Salinitas optimum untuk pertumbuhan benih kepiting bakau Scylla serrata dalam sistem resirkulasi. Jurnal Akuakultur Indonesia 14: 50-57.

Jewlaika L, Mubarak, Nurrachmi I. 2014. Studi padatan tersuspensi di perairan Pulau Topang Kabupaten Kepulauan Meranti Provinsi Riau. Jurnal Perikanan dan Kelautan 19: 53-66.

Karim MY. 2005. Kinerja pertumbuhan kepiting bakau betina Scylla serrata pada berbagai $\mathrm{pH}$ media dan evaluasinya pada $\mathrm{pH}$ optimum dengan kadar protein pakan berbeda [Disertasi]. Bogor: Institut Pertanian Bogor.

Karim MY. 2007. Pengaruh osmotik pada berbagai $\mathrm{pH}$ media terhadap vitalitas kepiting bakau Scylla olivacea betina. Jurnal Protein 14: 88-93

[KMNLH] Kementerian Menteri Negara Lingkungan Hidup. 2009. Peraturan menteri negara lingkungan hidup No 28 Tahun 2009 tentang daya tampung beban pencemaran perairan umum. Jakarta (ID): KMNLH. 
[KKP] Kementerian Kelautan Dan Perikanan. 2010. Sembilan komoditas perikanan jadi unggulan. www.kkp.go.id [10 Juli 2013].

Salim HT, Kusuma MSB, Nazili. 2006. Pemodelan hubungan hujan, limpasan dan kapasitas erosi pada suatu DAS yang masuk ke Palung Sungai. ITB Journal of Science 38: 51-72.

Suprapto D, Widowati I, Yudiati E, Subandiyono. 2014. Pertumbuhan kepiting bakau Scylla serrata yang diberi berbagai jenis pakan. Jurnal Ilmu Kelautan 19: 202-210

Ma YC, Yang YJ, Wang GL. 2013. Effects of salinity challenge on the immune factors of Scylla serrata. Acta Agriculturae Zhejiangensis 22: 479-484.

Nisa K, Marsi, Fitriani M. 2013. Pengaruh pH pada media air rawa terhadap kelangsungan hidup dan pertumbuhan benih ikan gabus Channa striata. Jurnal Akuakultur Rawa Indonesia 1: 57-65.

Nurdiani R, Zeng C. 2007. Effects of temperature and salinity on the survival and development of mud crab Scylla serrata (Forsskål) larvae. Aquaculture Research 38: 1.529-1.538.

Nurhidayat, Nirmala K, Djokosetyanto D. 2012. Efektivitas kinerja media biofilter dalam sistem resirkulasi terhadap kualitas air untuk pertumbuhan dan sintasan ikan red rainbow Glossolepis incisus Weber. Jurnal Riset Akuakultur 7: 89-96.

Ockwell DG. 2008. Energy and economic growth: Grounding our understanding in physical reality. Energy Policy 36: 4.600-4.604.

Rodriguez EM, Parado-Estepa FD, Quinitio ET. 2007. Extension of nursery culture of Scylla serrata (Forsskal) juveniles in net cages and ponds. Aquaculture Research 38: 1.588-1.592.

Rusdi I, Karim Y. 2006. Salinitas optimum bagi sintasan dan pertumbuhan crablet kepiting bakau Scylla paramamosain. Jurnal Kelautan 6: 149-157.

Sangari JRR, Toloh BH. 2015. Potensi pertumbuhan kepiting bakau Scylla serrata di perairan Pulau Mantehage, Taman Nasional Bunaken Sulawesi Utara. Jurnal Ilmiah Platax 3: $1-9$.

Sartje L. 2010. Osmoregulasi pada hewan akuatik. Jurnal Perikanan dan Kelautan 6: 46-50.

Siahainenia L. 2009. Inventarisasi jenis, struktur populasi dan potensi reproduksi kepiting bakau Scylla spp. pada ekosistem mangrove desa Passo. Journal of Marine Research 8: 103-110.

Sousa T, Domingos T, Poggiale JC, Kooijman . 2010. Dynamic energy budget theory restores coherence in biology. Biological Sciences 365: 3.413-3.428.

Supriyono E, Supendi A, Nirmala K. 2007. Pemanfaatan zeolit dan karbon aktif pada sistem pengepakan ikan corydoras Corydoras aenus. Jurnal Akuakultur Indonesia 6: 135145.

Tseng YC, Hwang PP. 2008. Some insights into energy metabolism for osmoregulation in fish. Comparative biochemistry and physiology part C. Toxicology and Pharmacology 148: 419-429.

Vijayavel, Gopalakrishnan KS, Balasubramanian MP. 2007. Sublethal effect of silver and chromium in the green mussel Perna viridis with reference to alternations in oxygen uptake, filtration rate and membrane bound ATPase system as biomarkers. Chemosphere 69: 979-986.

Watkins D, Cooperstein SJ, Lazarow A. 2008. Effect of alloxan on permeability of pancreatic islet tissue in vitro. American Journal of Physiology 207: 436-440. 